\title{
Application of Bio Fertilizer and Biogas Sludge to Curly Red Chili (Capsicum annuum L.)
}

\author{
Dwi Umi Siswanti ${ }^{1 *}$, Utaminingsih, Melinda Fajar Lestari and Hamdian \\ Faculty of Biology, Universitas Gadjah Mada, Jl. Teknika Selatan, Senolowo, Sinduadi, Mlati, Sleman, \\ Yogyakarta 55281 \\ *dwiumi@ugm.ac.id
}

Submitted: May 27, 2019; Accepted: November 22, 2019

\begin{tabular}{ll}
\hline Keywords: & Abstact Curly red chili (Capsicum sp.) is an important agricultural commodity in \\
Bio-fertilizer; & Indonesia. The pattern of conventional cultivation using inorganic fertilizers has \\
biogas; chili; $;$ & caused high production costs. While the level of spiciness of chili determined by \\
growth; & capsaicin levels is strongly influenced by nutrients in the growing media. Bio \\
sludge; & fertilizer and sludge biogas are the organic fertilizers proved to be able to increase \\
Wukirsari. & the growth and productivity of rice plants. The aim of this study is analizing growth \\
& parameters and chlorophyll content, measure capsaicin levels in curly red chilli \\
& (which is given bio fertilizer and biogas sludge biogas in various dosage) and \\
& determine the optimum dose of the fertilizer. The study was conducted at an \\
& agricultural demonstration plot in Wukirsari Village, Cangkringan, Sleman. The \\
& study design used RCBD (Randomized Complete Block Design). The data were \\
& analyzed by ANOVA (Analysis of Variance) followed by DMRT (Duncan's Multiple \\
& Distance Test) at the 95\% confidence level. The highest growth parameters was \\
& obtained on curly red chili plants which were given sludge biogas 36 mL + bio \\
& fertilizer $10 \mathrm{~L} /$ ha. Thus, it can be concluded that the most appropriate dose of curly \\
red chili is $36 \mathrm{~mL}$ sludge biogas + bio fertilizer $10 \mathrm{~L} / \mathrm{ha}$.
\end{tabular}

\section{INTRODUCTION}

The community service program based on the development of the partner villages was carried out in the Sruni hamlet, Wukirsari. The community service program of LPPM UGM (now DPkM UGM) work at Wukirsari village since 2013. The community service program carried out by our team during periods 2013 and 2014 has succeeded in increasing grain production, cost efficiency and improving cultivation systems into integrated organic systems (Siswanti, 2015). The community service program in 2015 has succeded to make infrastructure bio fertilizer and manure plus which were built by the community, to make integrated organic farming demonstration plots as a demonstration area for the community, to build biogas reactors that are used by residents to fuel gas stoves (Siswanti et al., 2015). The community service program in 2016 produced biogas infrastructure and strengthening integrated organic farming. Chili 
productivity in Indonesia is unstable following the season and environmental conditions. Chili production in 2010 experienced a decline compared to 2009 from $1,378,727$ tons to $1,332,356$ tons (BPS, 2011). The BPS data in 2015 stated that large red chili production increased in 2014 compared to 2013 at 61,730 tons $(6.09 \%)$ to $1,075,000$ tons. Production fluctuations and chili prices are caused by diseases, pests and climate change which results in erratic rainfall. The price of red chili in early 2017 ranges from Rp. 78,947/kg, up to $33.21 \%$ compared to January 2016, which was at Rp. $35,412 / \mathrm{kg}(\mathrm{BPS}, 2017)$.

\section{LITERATURE}

Chili plants can grow well on soil with sufficient moisture content. Some regions in Indonesia, especially marginal areas have limitations in low or dry water levels. Dry or too runny farmland will cause root function and growth to be disrupted. As a result, plant growth is also disturbed so that flower and fruit production will decline (Mubarokah et al., 2015). Dry land in the form of ultisol land covers 47.5 million ha and oxisol covers 18 million hectare in Indonesia (Yuwono, 2009).

The requirements for growing chili plants are influenced by sunlight intensity, rainfall, temperature and humidity, wind, altitude factors, and soil conditions. The ideal temperature for chili cultivation is $24-28^{\circ} \mathrm{C}$. At certain temperatures such as $15^{\circ} \mathrm{C}$ and more than $32^{\circ} \mathrm{C}$, the plant will produce less good chili. Growth is hampered if the daily temperature in the cultivation area is too cold. According to Tjahjadi (1991), chili plants can grow in the dry season if sufficient irrigation is carried out regularly. Light intensity required is full irradiation. The rainfall should be at $800-2000 \mathrm{~mm} / \mathrm{year}$ with $80 \%$ plant humidity.

The height for planting chili plants is below 1,400 masl from the lowlands to the highlands. In highland areas, chili plants can grow but not optimal. Chili plants could fit at flat ground. Chili plants can also grow and adapt well to various types of soil, ranging 
from sandy soil to clay (Harpenas et al., 2010). The growth of chili plants will be optimum if planted in soil with $\mathrm{pH}$ 6-7, fertile, and contain a lot of nutrients (Sunaryono and Rismunandar, 1984). Whereas, according to Tjahjadi (1991), chili plants can grow in soil conditions that contain essential nutrients (such as elements $\mathrm{N}$ and $\mathrm{K}$ ) and are not in a waterlogged condition.

The optimal growth of chili plants supported by appropriate environmental factors and nutrients. Bio fertilizer (organic liquid fertilizer) is very beneficial for plants that have limitations in absorbing solid fertilizers that are applied through the soil. Giving liquid organic fertilizer through leaves helps to overcome these limitations. The advantages of liquid organic fertilizer are nutrients contained in it easily absorbed by plants. Nutrients from liquid fertilizer are absorbed by leaves through leaf stomata (Maruapey, 2015).

Cow urine can be used as bio fertilizer. Fertilizing using fermented cow urine can increase vegetable production. The urine of the cow contains elements of $\mathrm{N}, \mathrm{P}, \mathrm{K}$ and $\mathrm{Ca}$ which are quite high and can increase the resistance of plants to disease attacks. There are deferences results of urine before and after fermentation. Before fermentation, $\mathrm{pH}(7.2), \mathrm{N}(1.1 \%), \mathrm{P}(0.5 \%), \mathrm{K}(1.5 \%), \mathrm{Ca}(1.1 \%)$ yellow, and strong odor. Whereas after fermentation, $\mathrm{pH}(8.7), \mathrm{N}(2.7 \%), \mathrm{P}(2.4 \%) \mathrm{K}(3.8 \%), \mathrm{Ca}(5.8 \%)$ black color and reduced odor (Rizqiana, et. al., 2007). The urine of the cow contains a growth stimulant and in terms of its nutrient content, liquid manure from the urine of the cow has a higher nutrient content compared to its solid waste (Lingga and Marsono, 1999). The urine of the cow also has a positive influence on the vegetative growth of plants. Since the smell is typical, the urine of the cow can also prevent the arrival of various plant pests, so that the urine of the cow can also function as a pest control insect on plants (Susetyo, 2013).

In addition, the use of biogas waste can increase plant growth and development. Biogas is an alternative energy that is environmentally friendly. Biogas is produced in 
an anaerobic reactor with its energy components in the form of methane $\left(\mathrm{CH}_{4}\right)$, carbon dioxide $\left(\mathrm{CO}_{2}\right)$, nitrogen $\left(\mathrm{N}_{2}\right)$, and hydrogen sulfide $\left(\mathrm{H}_{2} \mathrm{~S}\right)$. Although biogas comes from waste treated in the reactor, biogas produces high energy, which is $26.9 \mathrm{MJ} / \mathrm{m}^{3}$ or 7.5 $\mathrm{kWh} / \mathrm{m}^{3}$ for biogas with $75 \% \mathrm{CH}^{4}$. The main advantages of biogas energy production are generating electricity and heat, reducing methane emissions, and extra profits from commercialization with energy companies (Rosa et al., 2017).

During the biogas production process as an energy source, biogas liquid waste will be produced in the form of biogas sludge. According to Wahyuni (2011), biogas sludge is a by-product of biogas in the form of mud. Biogas sludge contains a lot of nutrients which can be used as plant fertilizer. The high nutrient content in biogas sludge can increase soil fertility by improving soil physical, chemical, and biological properties. Sludge biogas has undergone anaerobic fermentation so that it can be directly used to fertilize plants. Based on the analysis of wet weight, the content in biogas waste liquid fertilizer is organic $\mathrm{C}$ (carbon) $48 \%, \mathrm{~N}$-total $2.9 \%, \mathrm{C} / \mathrm{N} 15.8 \%, \mathrm{P}_{2} \mathrm{O}_{5}$ 0.2\%, $\mathrm{K}_{2} \mathrm{O} 0.3 \%$ (House of Biogas Team, 2013).

Bio fertilizer is an organic fertilizer that contains non symbiotic microorganisms can improve N (Nitrogen), P (Phosphorus) level or function as decomposers (Deshmukh et al., 2007). Bio-fertilizer has been applied in various studies in waste management and improving the quality of food production as a solution to increase land productivity and quality of crop production. Biofertilizer application is needed by plant commodities in order to provide important nutrients such as $\mathrm{N}$ and $\mathrm{K}$. One of the horticultural commodities is curly red chilli, which has high economic value in Indonesia.

Siswanti et al. (2011) stated that the rice planton the Ngawen rainfed land in Gunung Kidul showed an increase productivity after being given bio fertilizer treatment. The study also received a bio fertilizer dose of 10-15 liters/ha as the optimal dose for rainfed land. According to Siswanti and Rahmawati (2013), three rice varieties namely 
Situbagendit, Ciherang, and Inpari 20 had optimal growth and an increase in soil nutrient content after application of bio fertilizer in rice fields affected by the Merapi eruption in 2010. Siswanti and Agustina (2014) stated that the combination of bio fertilizer and vegetative decomposer had an effect on increasing leaf chlorophyll levels in two rice varieties (Menthik Wangi and Segreng). This combination also provides a good response to the increase in Nitrate Reductase Activity (NRA) on the leaves of the Segreng rice plant flag.

The use of organic fertilizer from biogas waste from cow manure has several benefits including increasing the formation of leaf chlorophyll, increasing plant vigor so that the plants become sturdy and increasing plant resistance to drought (Rizqiani et al., 2007). Sludge biogas free of pathogens and capable of killing disease-causing organisms in plants. As a keeper of soil moisture, slude biogas can reduce the growth of weeds because it can add topsoil and increase the water content in the soil (Handaka, 2012).

The study aimed to analyze the growth and chlorophyll content of plants, measure the capsaicin content, and find the optimum dose of bio fertilizer fertilizersludge biogas biogas for curly red chili plants that have the highest growth and capsaicin levels.

\section{RESEARCH DESIGN}

Planting of curly red chili plants (Capsicum annuum L.) was carried out in Wukirsari Village, Cangkringan, Sleman, Yogyakarta in April - July 2017. While testing leaf chlorophyll levels and testing of capsaicin levels was conducted at FALITMA laboratory at Faculty of Biology and Organic Chemistry Laboratory at Faculty of Mathemathics and Natural Saince Universitas Gadjah Mada. The growth parameters 
were plant height, number of leaves and chlorophyll content using the Arnon Method (1949).

This study has a treatment factor, including treatment of the use of different fertilizer doses consisting of eight treatments. The treatment design uses RCBD (Randomized Complete Block Design) with five replications. The following is the experimental design of the study (Tabel 1)

Table 1. Treatment design

\begin{tabular}{cc}
\hline No & Treatment \\
\hline 1 & Control (NPK fertilizer) \\
2 & Biogas sludge $12 \mathrm{ml}$ \\
3 & Biogas sludge $24 \mathrm{ml}$ \\
4 & Biogas sludge $36 \mathrm{ml}$ \\
5 & Bio fertilizer $10 \mathrm{l} / \mathrm{ha}$ \\
6 & Biogas sludge $12 \mathrm{ml}+$ Bio fertilizer $101 / \mathrm{ha}$ \\
7 & Biogas sludge $24 \mathrm{ml}+$ Bio fertilizer $101 / \mathrm{ha}$ \\
8 & Biogas sludge $36 \mathrm{ml}+$ Bio fertilizer $101 / \mathrm{ha}$ \\
\hline
\end{tabular}

Source: primary data (2017)

Each treatment with 5 replications so that the total units were 40 experimental samples.

Data were analyzed using ANOVA followed by DMRT test with a confidence level of $95 \%(\alpha=0.05)$. Data analysis was performed using the $16^{\text {th }}$ edition of SPSS software.

\section{RESULT AND DISCUSSION}

Measurement of growth parameters was carried out when curly red chili plants were in the vegetative phase. The vegetative phase of curly red chili plants in this study lasted for eight weeks. The first aspect of vegetative growth measured is plant height. Measuring the height of this plant is done once week and plants are given fertilizer treatment until they reach a maxmum phase (approximately in eight week). The measurement results are presented in Figure 1. 


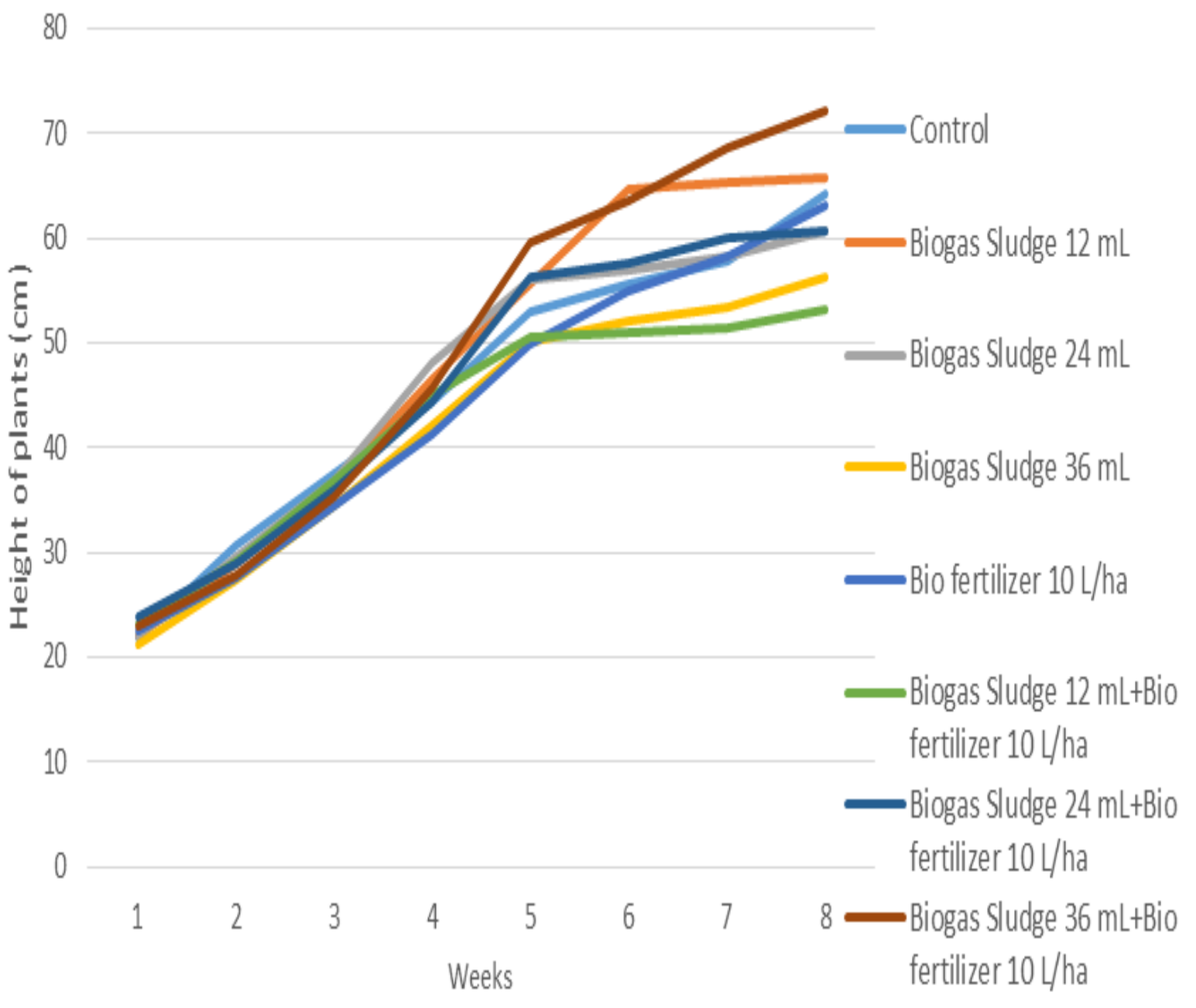

Source: Siswanti and Lestari (2019)

Figure 1. The height of the curly red chili plant (Capsicum annuum L.) after administration of bio fertilizer and biogas sludge at eight weeks.

Based on Figure 1, the height of curly red chili plants shows an increase with age. The application of bio fertilizer and biogas sludge with dose variations in general can increase plant growth compared to NPK controls. The highest plant height was found in fertilizer treatment with biogas sludge dosage $36 \mathrm{~mL}$ and bio fertilizer $10 \mathrm{~L} / \mathrm{ha}$, while the lowest plant height was in fertilizer treatment with biogas sludge dosage 12 $\mathrm{mL}$ and bio fertilizer $10 \mathrm{~L} / \mathrm{ha}$. The results of the measurement of the high average curly red chili plant stem at the eight week, are presented in Figure 2. 


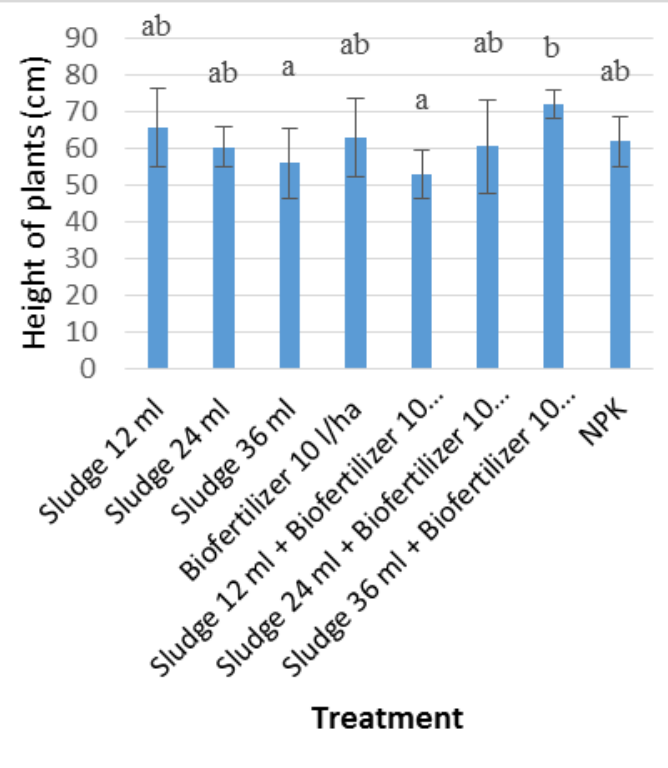

Source: Siswanti and Lestari (2019)

Figure 2. The average height of curly red chili (Capsicum annuum L.) results from bio fertilizer and biogas sludge application at the eight week.

Figure 2 shows the height of curly red chili plants in the eight week. Based on statistical analysis using DMRT with a confidence level of $95 \%(\alpha=0.05)$, it showed height of curly red chili plants after the application of bio fertilizer and biogas sludge in various concentrations with controls were not significantly different. This means that the application of bio fertilizer and biogas sludge is able to provide nutrients as well as inorganic fertilizer (NPK).

When compared with controls, the application of $12 \mathrm{~mL}$ biogas sludge; bio fertilizer $10 \mathrm{~L} / \mathrm{ha}$; and sludge biogas $36 \mathrm{~mL}$ and bio fertilizer $10 \mathrm{~L} / \mathrm{ha}$ increase the plant height. The dose sludge biogas $36 \mathrm{~mL}+$ bio fertilizer $10 \mathrm{~L} /$ ha has the highest height of plants compared to other doses and NPK application (control). It means this dose is the optimum for increasing the growth of high curly red chili plants.

Sludge biogas has a role as a nutrient mineral provider that is important during the growth and development of curly red chili plants (Bansal, 2014). The content of sludge biogas is rich in various plant nutrients, such as nitrogen, phosphorus, and potassium, which are macro nutrients needed by plants in large amounts (Susilo et al., 
2017). The role of these elements can increase overall plant growth (especially when plants are in the vegetative phase), accelerate the formation of fruit, flowers, and seeds, and increase plant resistance to disease (Endah, 2001). Increasing the dose of biogas sludge in curly red chili plants can increase the growth of plant, such as plant height.

The second aspect of vegetative growth measurement is the number of leaves. The number of leaves is calculated on the leaves that have opened perfectly. This measurement is carried out every seven days after transplanting and given treatment until the maximum vegetative phase (the eighth week after planting). The measurement results are presented in Figure 3.

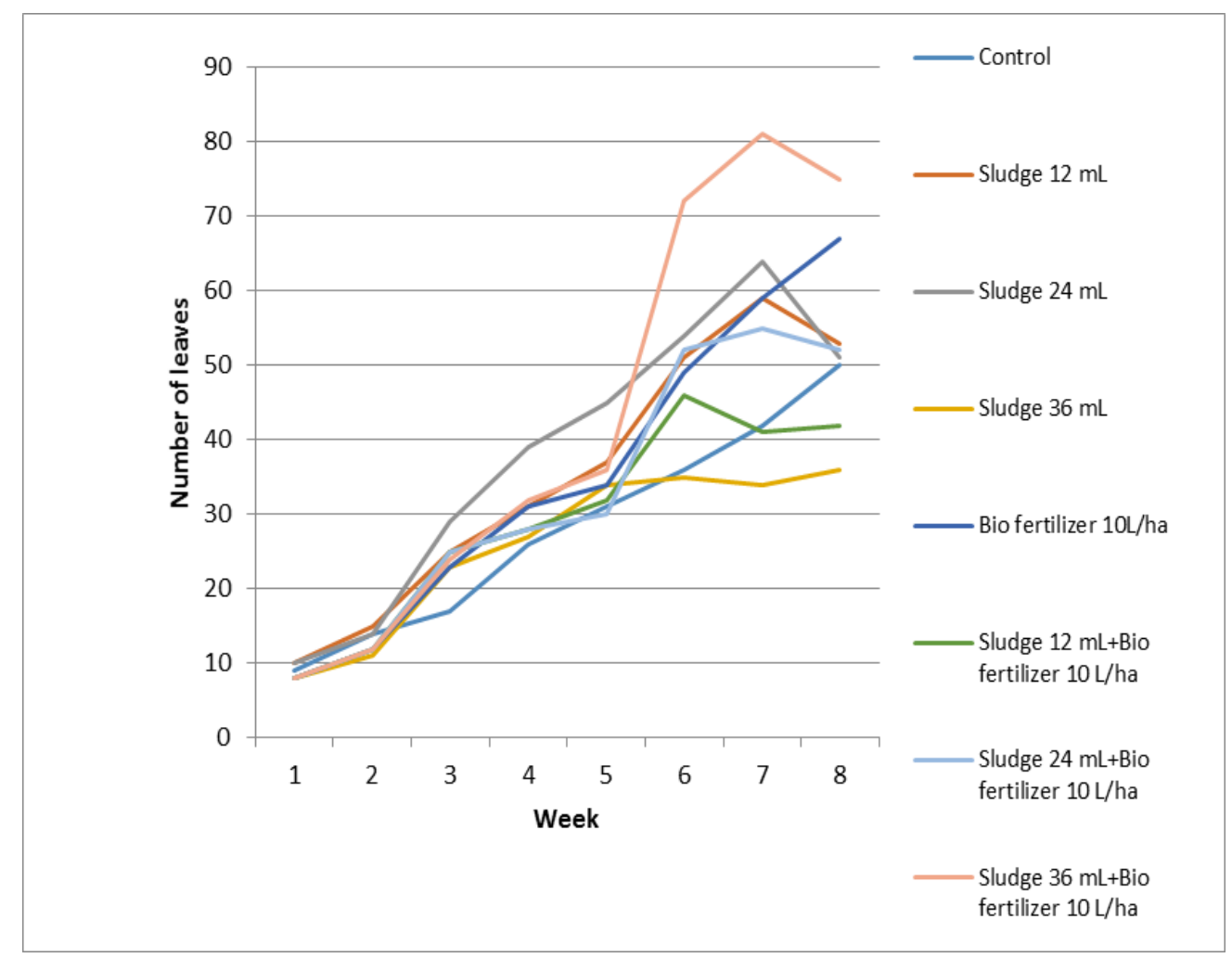

Source: Siswanti and Lestari (2019)

Figure 3. The rate of addition of the number of leaves of curly red chili (Capsicum annuиm L.) as a result of bio-fertilizer and biogas sludge.

Based on Figure 3, the number of leaves of curly red chili plants increases in proportion to the age of the plant. The highest number of leaves in plants with the application of biogas sludge $36 \mathrm{~mL}+$ bio fertilizer $10 \mathrm{~L} / \mathrm{ha}$ while the least number of 
leaves on plants with the application of $36 \mathrm{~mL}$ biogas sludge. The results of measurement of the number of leaves of curly red chili at eight weeks were presented in Figure 4.

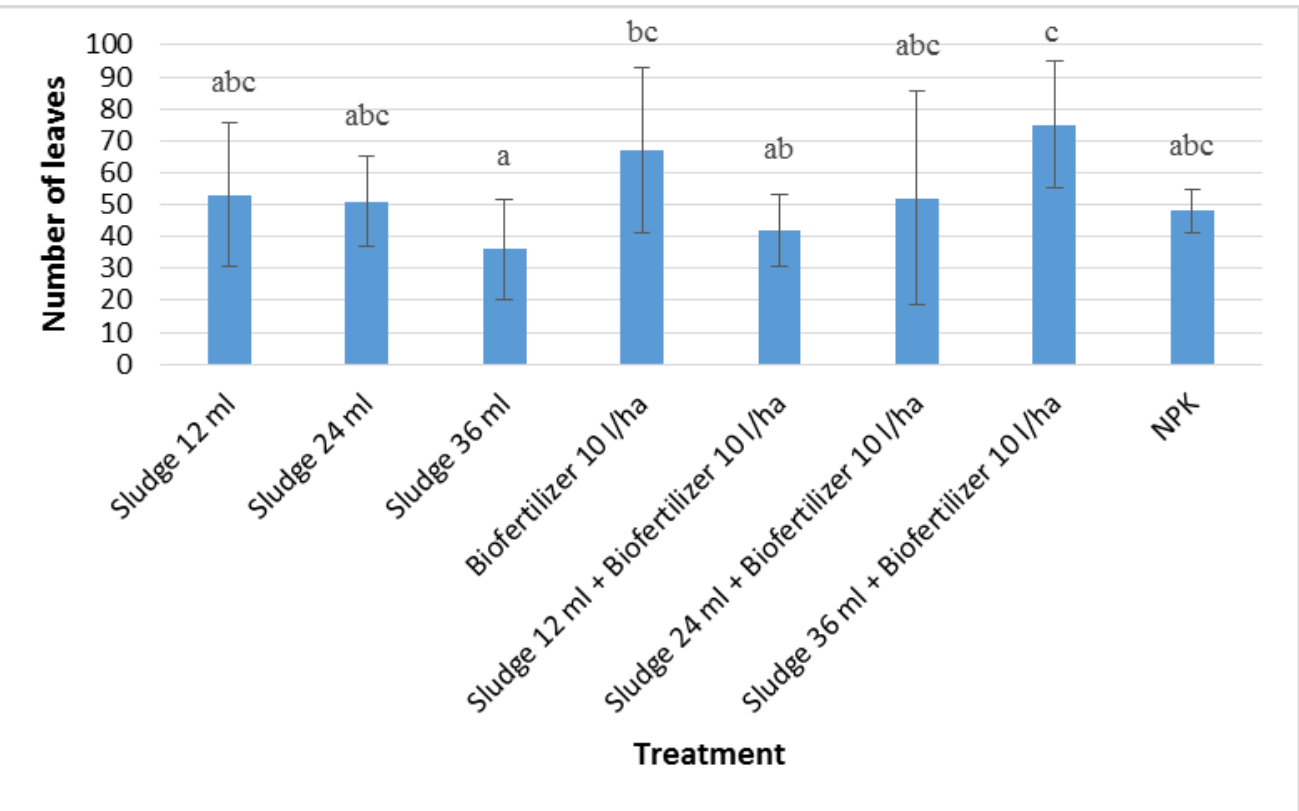

Source: Siswanti and Lestari (2019)

Figure 4. The number of leaves of the curly red chili plant was given by bio fertilizer and biogas sludge at the eighth week.

Based on statistical analysis using DMRT with a confidence level of $95 \%(\alpha=$ 0.05), the results of the average number of leaves using bio fertilizer and biogas sludge in various concentrations were not significantly different from controls. This shows organic fertilizer, bio fertilizer and biogas sludge to be able to provide nutrients for curly red chili plants to have the same leaf growth as the application of inorganic fertilizer (NPK).

The application of bio fertilizer and biogas sludge at various concentrations can increase the average number of leaves of curly red chili plants. Curly red chili plants have the highest number of leaves in the application of biogas sludge $36 \mathrm{~mL}+$ bio fertilizer $10 \mathrm{~L} / \mathrm{ha}$ and dose of bio fertilizer $10 \mathrm{~L} / \mathrm{ha}$, while the average number of leaves is the least available in the application of $36 \mathrm{~mL}$ biogas sludge. Based on the statistical analysis of DMRT with a confidence level of $95 \%(\alpha=0.05)$, there is a significant 
difference between the number of leaves biogas sludge $36 \mathrm{~mL}$ +bio fertilizer $10 \mathrm{~L} / \mathrm{ha}$ application compare with bio fertilizer $36 \mathrm{~mL}$ application and biogas sludge $12 \mathrm{~mL}+$ bio fertilizer $10 \mathrm{~L} / \mathrm{ha}$. This showed that treatment biogas sludge $36 \mathrm{~mL}+$ bio fertilizer $10 \mathrm{~L} / \mathrm{ha}$ and treatment bio fertilizer $10 \mathrm{~L} / \mathrm{ha}$ are more effective in growing the number of leaves in curly red chili plants compared to the application of $36 \mathrm{~mL}$ biogas sludge and biogas sludge $12 \mathrm{~mL}+$ bio fertilizer $10 \mathrm{~L} / \mathrm{ha}$.

Compared with controls, the application of bio-fertilizer and biogas sludge with $12 \mathrm{~mL}$ biogas sludge dose, $24 \mathrm{~mL}$ biogas sludge, bio fertilizer $10 \mathrm{~L} / \mathrm{ha}$, sludge biogas 24 $\mathrm{mL}$ and bio fertilizer $10 \mathrm{~L} / \mathrm{ha}$, and sludge biogas $36 \mathrm{~mL}$ and bio fertilizer $10 \mathrm{~L} / \mathrm{ha}$ have more leaves. The application of biogas sludge $36 \mathrm{~mL}$ and bio fertilizer $10 \mathrm{~L} / \mathrm{ha}$ in curly red chili plants had the highest number of leaves of plants compared to other doses and controls.

Based on this description, it can be seen that treatment five and treatment eight increase the number of curly red chili plant leaves, although statistical analysis does not provide a real difference. The higher concentration of bio fertilizer and biogas sludge given tend to be able to increase the number of leaves of curly red chili plants.

Application of biogas sludge $36 \mathrm{~mL}+$ bio fertilizer $10 \mathrm{~L} / \mathrm{ha}$ is the optimum dose to increase the number of curly red chili plant leaves. This occur because there is a balance between the biogas sludge and bio fertilizer so that the absorption by the plant roots becomes more optimum. Sludge biogas provides organic ingredients, while biofertilizer provides microbial decomposition of organic matter into nutrients for plants. High nutrient content in biogas sludge and bio fertilizer can improve the quality of curly red chili plants to produce more leaves. The nitrogen element contained in biogas sludge fertilizer plays a role in leaf growth, the leaves of the plant become wider with greener leaf colors (Sperling, 2007). 
Leaf chlorophyll content were measured using a spectrophotometer. This measurement was carried out at the maximum vegetative phase of the curly red chili plant which was at the eighth week. The measurement results are presented in Figure 5.

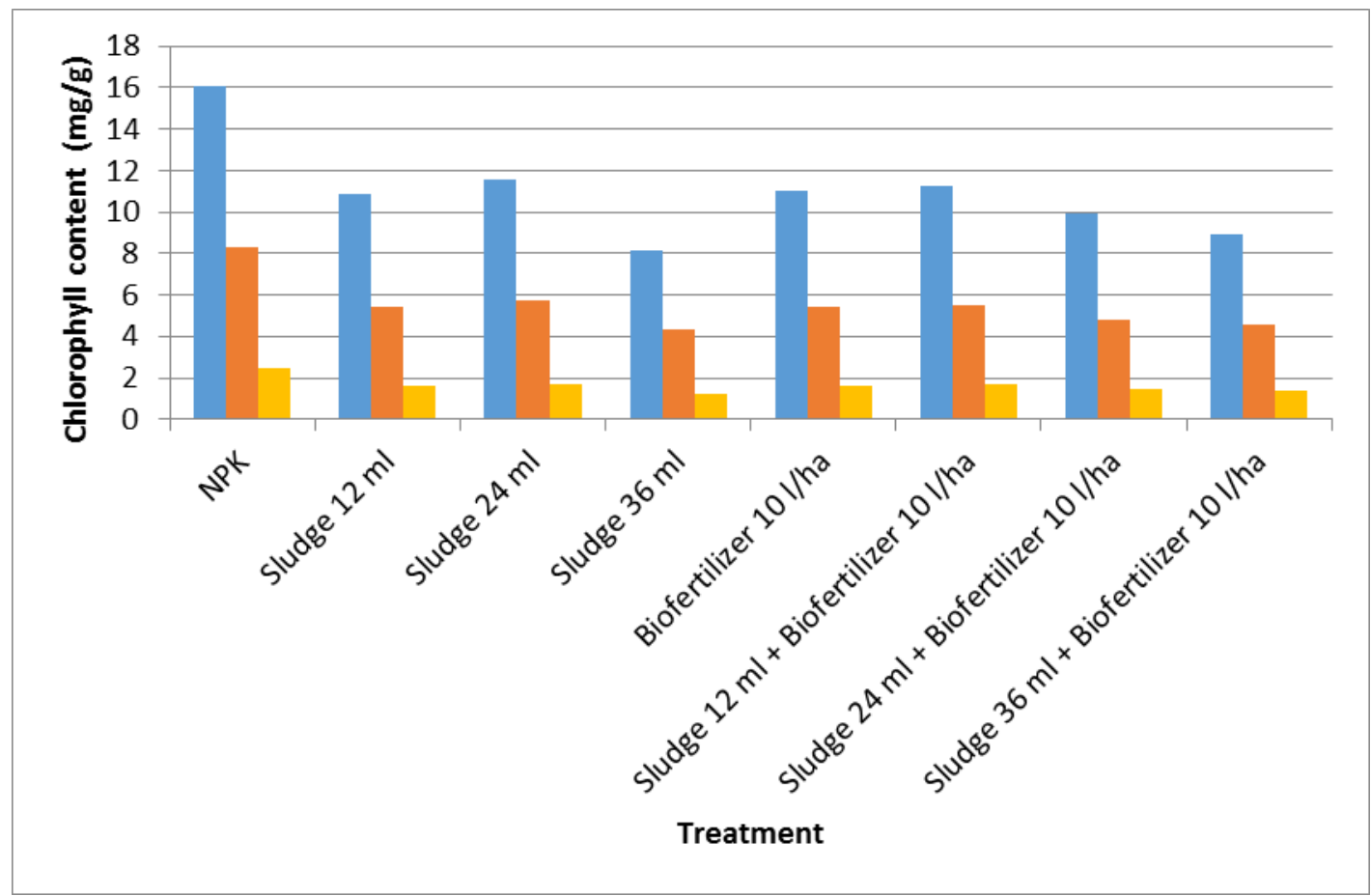

Sourcer: Siswanti and Lestari (2019)

Figure 5. Chlorophyll a, chlorophyll b, and total chlorophyll content of leaves of the curly red chili plant (Capsicum annuum L.) as a result of bio fertilizer and biogas sludge at the eighth week.

Note:

Blue $=$ Chlorophyll a

Red $=$ Chlorophyll b

Purple $=$ Total Chlorophyll

Based on Figure 5, the chlorophyll content of the leaves of curly red chili plants showed varied results at each dose of fertilizer given. Plants with treatment tended to have lower chlorophyll levels than that in the control. It is known that the highest chlorophyll content of leaves is in plants with NPK application (control), while the least of chlorophyll content of leaves is in treatment four. This is likely to occur because some chlorophyll is still at the stage of chlorophyll a (seen in the chlorophyll a content 
greater than chlorophyll b) and has not yet become chlorophyll b, because chlorophyll a is known as a chlorophyll bfprecursor (Robinson, 1980). Chlorophyll b is chlorophyll which acts as an antenna that collects light and transfer it to the reaction center. The reaction center is composed of chlorophyll a. Light energy will be converted into chemical energy in the reaction center which can be used for the reduction process in photosynthesis (Taiz and Zieger, 1991). The results of the measurement of the chlorophyll content of the leaves of curly red chili plants at the eight week are presented in Figure 6.

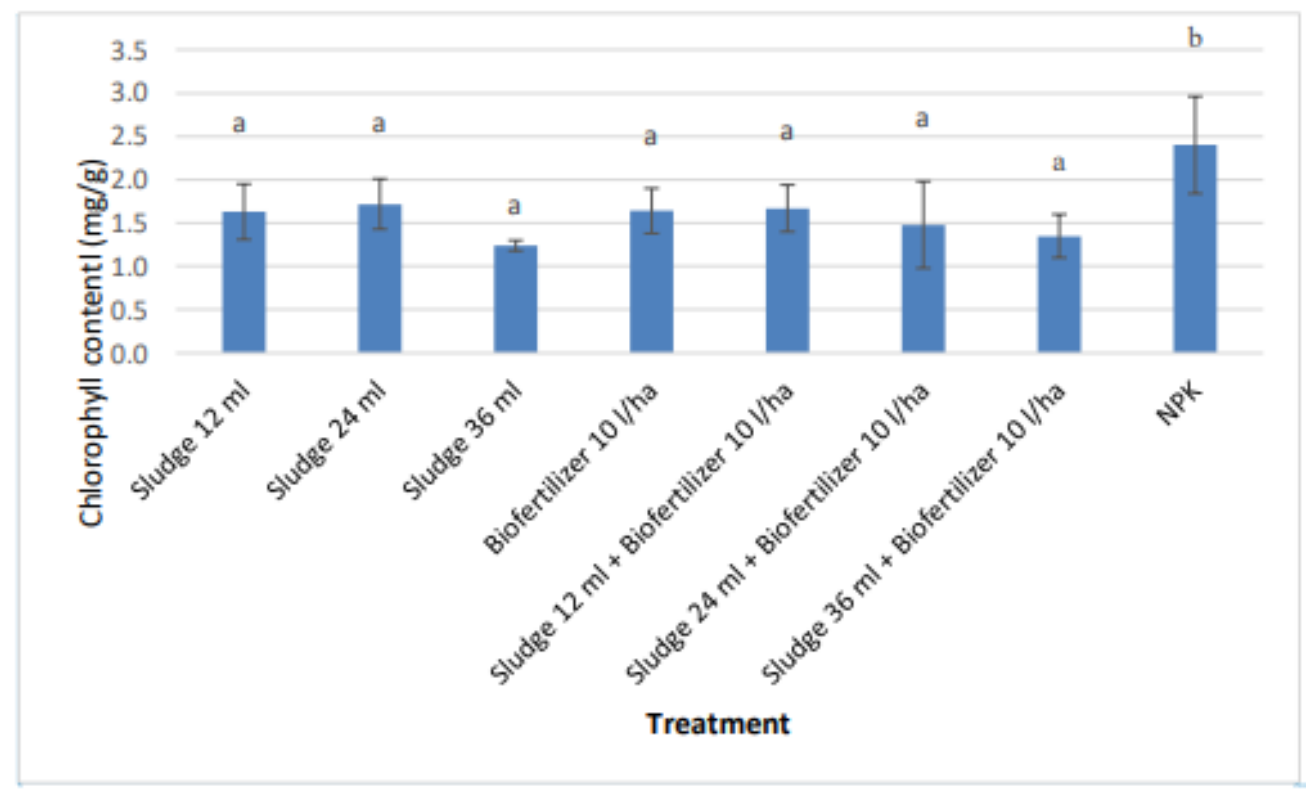

Source: Siswanti and Lestari (2019)

Figure 6. The total chlorophyll content of the leaves of the curly red chili plant (Capsicum annuum L.) as a result of bio fertilizer and biogas sludge.

Based on Figure 6, it can be seen that the total chlorophyll levels in all doses of bio-fertilizer and biogas sludge treatment are not significantly different from control. Control plant with the NPK application have the highest total chlorophyll content of the leaves, while the application of $36 \mathrm{~mL}$ biogas sludge has the lowest average total leaf chlorophyll content. 
The application of bio fertilizer and biogas sludge in various concentrations given is able to provide nutrients for plants to form the same chlorophyll as NPK (inorganic fertilizer) applications. Chlorophyll content of control plants were higher than chlorophyll content in treatment plants. These results can be caused by abundant and sufficient nutrients in plants with the application of bio fertilizer and biogas sludge capable of accelerating the vegetative growth of curly red chili plants. The plants have entered the generative phase faster than control. When curly red chili plants with treatments have entered the generative phase, the control plants with low nutrient causes the plants to be in the vegetative phase at the same age. According to Mengel and Ernest (2012), the low nutrient available for plants can cause the growth process to inhibit the plant. In its generative phase, plants that optimize nutrients are absorbed to form chilies and seeds in chili fruit, so that these nutrients are not fully used for growth and increase chlorophyll content in the leaves.

\section{CONCLUSIONS}

Based on the results of research on the physiological response of the curly chili plant bio fertilizer and biogas sludge application, it can be concluded that the growth of curly red chili plants is best in the application of $36 \mathrm{~mL}$ biogas sludge $+10 \mathrm{~L} / \mathrm{ha}$ biofertilizer. Curly red chili plants with various concentrations have lower chlorophyll content compared to controls.

Control plants optimize the nutrients absorbed by plants for growth and increase leaf chlorophyll content. Thus, it can be seen in the results of the total chlorophyll content of curly red chili plants in the control having a higher total chlorophyll content compared to all curly red chili plants with the application of bio-fertilizer and biogas sludge. 


\section{ACKNOWLEDGMENTS}

The Researher would like to thank Community Service Directorate UGM and Tani Makmur Farmers Group of Wukirsari Village, and all residents of Wukirsari Village, Cangkringan, Sleman.

\section{REFERENCES}

Badan Pusat Statistik. 2011. Luas Panen, Produksi dan Produktivitas Cabai 2009-2010. Downloaded in 25 Februari 2017. from http: www.bps.go.id

Badan Pusat Statistik. 2017. Laporan Bulanan Data Sosial Ekonomi Januari 2017. Downloaded in 25 Februari 2017 from http: www.bps.go.id

Handaka, W. 2012. Bio-slurry Hasil Proses Biogas untuk Pertanian dan Perkebunan $\begin{array}{lll}\text { Ramah } & \text { Lingkungan. } & \text { Downloaded }\end{array}$ http://bengkulu2green.wordpress.com/author/bengkulu2green/

Harpenas, Asep and R. Dermawan. 2010. Budidaya Cabai Unggul. Penebar Swadaya. Jakarta.

House of Biogas Team. 2013. Pedoman, Pengguna, Pengawas Pengelolaan dan Pemafaatan Bio Slurry. Yayasan Rumah Energi. Jakarta.

Lingga, P. and Marsono. 2004. Petunjuk Penggunaan Pupuk. Penebar Swadaya. Jakarta.

Maruapey, A. 2015. Pengaruh Pupuk Organik Limbah Biogas Cair Kotoran Sapi Terhadap Pertumbuhan Dan Produksi Tanaman Jagung Manis (Zea Mays Saccharata Sturt). Jurnal Agroforestri. 10 (3): 191-200.

Mengel, K. and Ernest A. K. 2012. Principles of Plant Nutrition. Springer Science \& Business Media. Giessen. 
Mubarokah L.L. 2013. Respon Karakter Morfo-fisiologis dan Akumulasi Bioaktif Antosianin Tanaman Bayam Merah (Alternanthera amoena Voss) terhadap Cekaman Kekeringan. Skripsi. UIN Sunan Kalijaga. Yogyakarta

Nugroho, L.H., H.T. Hastuti., T. Astutiningsih and I. Sumardi. 2006. Karakteristik Cabai rawit (Capsicum frutescens L.) yang Ditumbuhkan Secara Hidroponik. Berkala Ilmiah Biologi.Vol 5, No 1: 13-21.

Rizqiani, N. F. Ambarwati, E. and Yuwono, N. W. 2007. Pengaruh Dosis dan Frekuensi Pemberian Pupuk Organik Cair Terhadap Pertumbuhan dan Hasil Buncis (Phaseolus vulgaris L.) Dataran Rendah. Jurnal Ilmu Tanah dan Lingkungan. Vol 7: 43-53.

Robinson T. 1980. The organic constituents of higher plants. 4th ed. Cordus Press. North Amherst, Mass.

Rosa, A. P., C. A. L. Chernicharo, L. C. S. Lobato, R. F. Padilha, and J. M. Borges. 2017. Assessing The Potential of Renewable Energy Sources (Biogas and Sludge) in A Full-Scale UASB-Based Treatment Plant. Renewable Energy.Elsevier. 30: 1-6.

Siswanti, D.U., Maryani, H. Hartiko and D. Rahmawati. 2011. Plant Response and Nitrate Reductase Activity in Vivo on Rice (Oryza sativa L.) Cultivars IR-64 to Biofertilizer Application and Drought. Poster. International Conference of Biological Science.

Siswanti, D.U. and D. Rahmawati. 2013. Plant Growth of Three Cultivars of Rice (Oryza sativa L.) against Bio Fertilizer Application and Agriculture Soil Condition Post Merapi Eruption 2010. Journal Biogenesis. Vol 1. No. 2: 110-115. Siswanti, D.U. and R.V. Agustin. 2014. Physiological Response of Rice (Oryza sativa L.) "Segreng" and "Menthik Wangi" Against Bio Fertilizer Application and Decomposers. Journal Biogenesis. Vol.2 No.2: 89-93. 
Siswanti, D.U. 2015. Integrated Organic Farming to Restore Soil Fertility of Field efected by Merapi Eruption 2010 and to reach the prosperous village at Wukirsari Village. Indonesian Journal of Community Engagement. Volume 01, Number 1, September 2015. Pp: $65-78$.

Siswanti, D.U. and M. F. Lestari. 2019. Growth Rate and Capsaicin Level of Curly Red Chili (Capsicum annuum L.) on Biofertilizer and Sludge Biogas Application. Jurnal Biodjati. 4(1), 126-137.

Sperling, M. V. 2007. Activated Sludge and Aerobic Biofilm Reactors. IWA Publishing. New York. pp. 54-55.

Sunaryono, Handro and Rismunandar. 1984. Kunci Bercocok Tanam Sayuran-Sayuran Penting Di Indonesia. Sinar Baru. Bandung.

Susetyo, N. A. 2013. Pemanfaatan Urin Sapi sebagai POC (Pupuk Organik Cair) dengan Penambahan Akar Bambu Melalui Proses Fermentasi Dengan Waktu yang Berbeda. Skripsi. Fakultas Keguruan dan Ilmu Pendidikan. pp. 1-15.

Susilo, B., Retno D., and Ni'matul I. 2017. Teknik Bioenergi. Universitas Brawijaya Press. Malang. p. 255.

Taiz.L and E. Zeiger. 1991. Plant Physiology $3^{\text {th }}$ EditionSinauer Association Sunderland.

Tjahjadi, N. 1991. Bertanam Cabai. Penerbit Kanisius. Yogyakarta.

Wahyuni, S. 2011. Menghasilkan Biogas dari Aneka Limbah. Edisi Pertama. PT Agro Media Pustaka: Jakarta.

Yuwono, N. W. 2009. Membangun Kesuburan Tanah di Lahan Marginal. Jurnal Ilmu Tanah dan Lingkungan. 9: 137-141. 


\section{ATTACHMENTS}

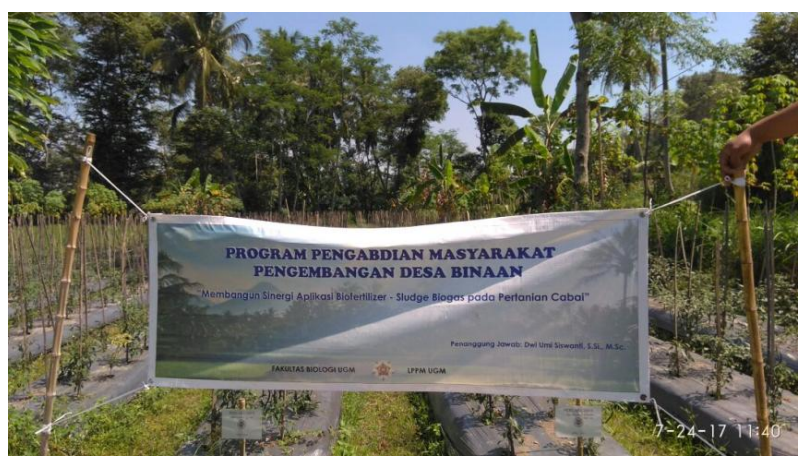

Source: Primary data (2017)

Figure 7. The organic chili farming demonstration plot in Wukirsari Village.

\section{Source: Primary Data (2017)}

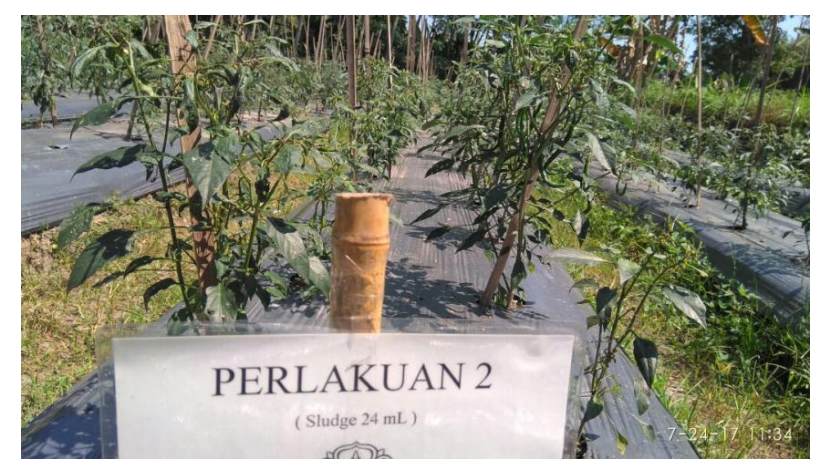

Figure 8. Curly red chili plants in the demonstration plot. 